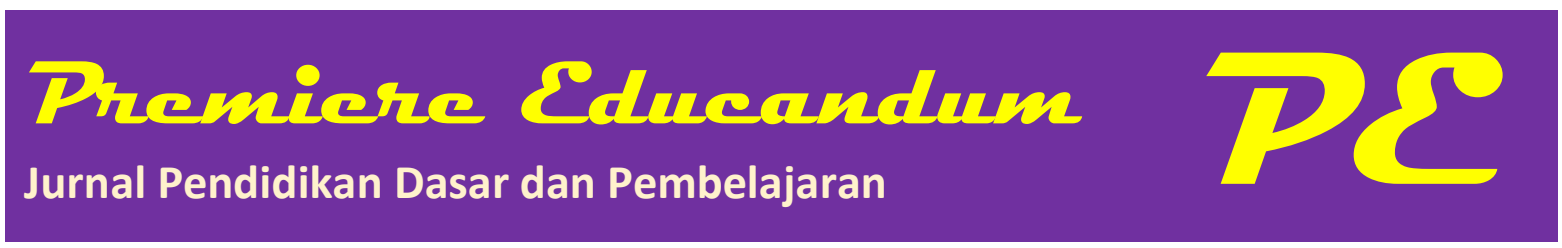

Premiere Educandum 7(1) 1 - 8 Juni 2017

Copyright $\odot 2017$ PGSD Universitas PGRI Madiun

P - ISSN: 2088-5350/E - ISSN: 2528-5173

Available at: http://e-journal.unipma.ac.id/index.php/PE

\title{
Peningkatan Pemahaman Konsep Bangun Datar Melalui Pendekatan Konstruktivisme Berbasis Teori Van Hiele
}

\author{
Nyai Cintang'), Ari Meiza Nurkhasanah ${ }^{2)}$ \\ ${ }^{1}$ Program pascasarjana,Universitas Negeri Semarang \\ email: nyaicintang@gmail.com \\ ${ }^{2}$ Guru Sekolah Dasar Negeri Pekunden, Banyumas \\ email: arimeiza05@gmail.com
}

\begin{abstract}
This action research aimed to improve the understanding of the concept. The subject of this study was grade $3^{\text {th }}$ of SDN Pekunden amounted to 18 students, consisted of 11 male students and 7 female students. The data were analyzed by descriptive percentage. The results showed an increase in understanding of the concept. In initial tests, there are misconception with an average score of student 55.9 and percentage $11 \%$ with very low categories. The average in cycle I increased to 88.69 and percentage $100 \%$ with very high category. In cycle II, the average percentage is 86 and percentage 100\% with very high category. The purpose of cycle II is to improve the understanding of the concept of students on the next level. In cycle I, students are able to reach of visualization, and than in cycle II students are able to level visualization and analysis. The conclusion of this research is through constructivism approach based on van hiele theory can enhance the ability of understanding the concept of students in geometry learning grade $3^{\text {th }}$ SDN Pekunden.
\end{abstract}

Key Word : Van Hiele Theory, Constructivism Approach, Understanding the Concept

\section{Abstrak}

Penelitian tindakan kelas ini bertujuan untuk meningkatkan kemampuan pemahaman konsep siswa kelas III SDN Pekunden. Subjek penelitian berjumlah 18 siswa, terdiri dari 11 siswa laki-laki dan 7 siswa perempuan. Data yang diperoleh kemudian dianalisis menggunakan deskripsi prosentase. Hasil penelilitan menunjukkan adanya peningkatan pemahaman konsep siswa. Pada tes awal masih terdapat miskonsepsi dengan rata-rata 55,9 dan prosentase keberhasilan siswa $11 \%$ dengan kategori sangat rendah. Pada siklus I rata-rata meningkat menjadi 88,69 dan prosentase keberhasilan siswa 100\% dengan kategori sangat tinggi. Pada siklus II rata-rata 86 dan prosentase keberhasilan 100\% dengan kategori sangat tinggi. Siklus II dilakukan untuk meningkatkan kemampuan pemahaman konsep siswa pada level selanjutnya. Pada siklus I siswa mampu mencapai tingkat visualisasi, dan terjadi peningkatan pada siklus II. Siswa mampu menguasai level visualisasi dan analisis. Simpulan penelitian ini adalah melalui pendekatan konstruktivisme berbasis teori van hiele dapat meningkatkan kemampuan pemahaman konsep siswa pada pembelajaran geometri materi bangun datar kelas III SDN Pekunden.

Kata Kunci : Teori Van Hiele, Pendekatan Konstruktivisme, Pemahaman Konsep

\section{A. PENDAHULUAN}

Pemahaman konsep matematika merupakan suatu kemampuan yang mendasari kemampuan-kemampuan matematika yang lain. Belajar konsep merupakan batu pembangun berpikir dan dijadikan dasar bagi proses mental yang lebih tinggi untuk merumuskan prinsip dan generalisasi (Dahar, 2011). Siswa harus mengetahui aturan-aturan yang relevan yang didasarkan pada konsep-konsep yang diperolehnya untuk memecahkan masalah. Oleh karena itu, mengembangkan kemampuan pemahaman konsep 
matematika merupakan salah satu tujuan pembelajaran harus dicapai. Konsep yang salah akan menyebabkan miskonsepsi. Dahar (2011: 155) menyatakan bahwa miskonsepsi merupakan penghambat dalam belajar. Oleh karena itu, miskonsepsi sedapat mungkin ditiadakan.

Pembelajaran harus memperhatikan pengetahuan awal yang telah dimiliki siswa (Ausubel,1968). Guru yang mengajar hendaknya bertitik tolak pada gagasan yang telah dimiliki anak sebagai tolak ukur menyiapkan pembelajaran yang dapat mengurangi miskonsepsi dan meningkatkan kosep gagasan baru. Miskonsepsi yang tidak dibenahi pada jenjang SD akan tar sederhana terdiri dari bangun datar seiempat dan segitiga, Untuk mengetahui pemahaman siswa terhadap bangun segi empat diberikan beberapa pertanyaan pada tes awal.

Pertanyaan tes awal dikelompokkan menjadi empat kategori, yaitu : 1) pemahaman konsep kelompok bangun diperoleh melalui pembentukan dan asimilasi konsep. Proses penanaman konsep berdampak pada jenjang pendidikan selanjutnya. Jika miskonsepsi dibiarkan maka akan sulit untuk dilakukan perbaikan konsep. Menanamkan konsep sejak pendidikan dasar lebih mudah dari pada memperbaiki konsep yang telah melekat dan dianggap sebagai suatu kebenaran konsep dalam diri siswa.

Hasil analisis pemahaman konsep yang yang telah dimiliki 18 siswa kelas III SDN Pekunden menunjukkan bahwa terdapat kesalahan konsep yang berkaitan dengan bangun datar sederhana. Materi bangun da segiempat, 2) pemahaman konsep kelompok bangun jajar genjang, 3) pemahaman konsep bangun persegi, dan 4) pemahaman konsep kelompok bangun segitiga. Diagram 1 menunjukkan prosentase siswa yang mengalami miskonsepsi.

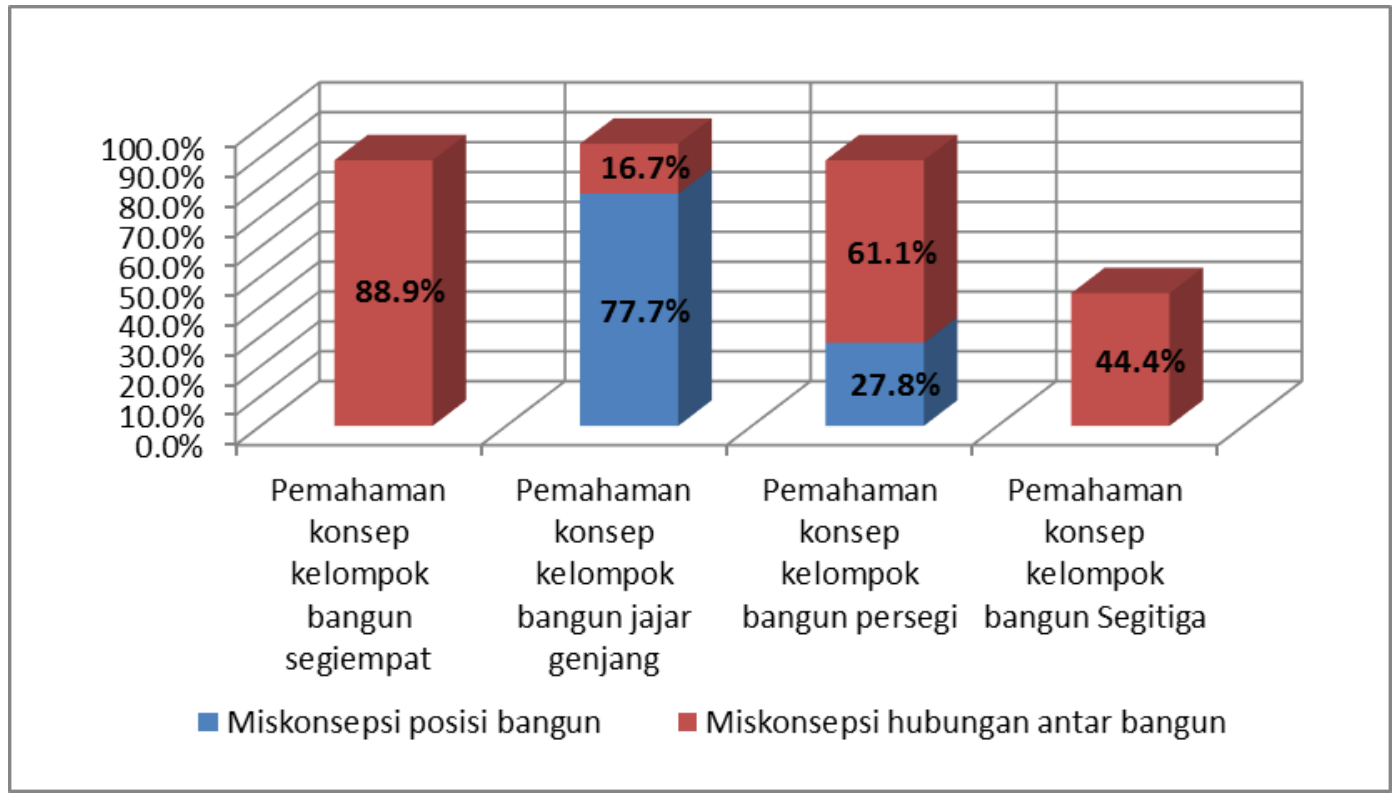

Gambar 1. Kondisi Awal : Miskonsepsi Bangun Datar Sederhana

Hasil analisis kategori pertama menunjukkan bahwa $88,9 \%$ siswa mengalami miskonsepsi kelompok bangun segiempat. Siswa yang mengalami miskonsepsi menganggap bahwa bangun yang merupakan segi empat adalah bangun datar persegi yang memiliki empat sisi yang sama panjang. Hanya dua siswa yang memiliki pemahaman konsep segi empat dengan tepat bahwa segi empat merupakan bangun yang memiliki empat ruas garis (sisi) dan segitiga adalah bangun yang memiliki tiga ruas garis (sisi).

Hasil analisis ketagori kedua 
menunjukkan bahwa $94 \quad \%$ siswa mengalami miskonsepsi kelompok bangun jajar genajang yang terdiri dari $77,7 \%$ siswa menganggap jajar genjang hanya dalam posisi biasa yaitu dengan posisi mendatar (dalam arah pandang pembaca) adalah sisi terpanjang, $16,7 \%$ siswa mengalami miskonsepsi dengan ragam bentuk belah ketupat sebagai jajar genjang jika diposisikan mendatar seperti jajar genjang. Kesalahan siswa disebabkan pada kebiasaan menggambar jajar genjang dalam posisi biasa, dan penjelasan guru yang selalu menampilkan bentuk bangun datar jajar genjang dengan posisi yang seperti biasa (mendatar dalam arah pandang pembaca). Akhirnya, siswa menganggap bahwa suatu bangun merupakan jajar genjang jika ditampilkan dalam posisi mendatar.

Hasil analisis ketagori ketiga menunjukkan bahwa $88,9 \%$ siswa megalami miskonsepsi kelompok bangun persegi yang terdiri dari $27,8 \%$ siswa hanya memilih bangun persegi biasa yaitu dalam posisi "mendatar" (menurut arah pandang pembaca), dan $61.1 \%$ siswa mengalami miskonsepsi dengan beragam bentuk. Siswa yang mengalami miskonsepsi menganggap suatu bangun adalah persegi jika ukurannya sama dan diletakkan dengan posisi mendatar.

Hasil analisis kategori keempat menunjukkan bahwa $44,4 \%$ siswa mengamami miskonsepsi kelompok bangun segitiga. Siswa menganggap hanya beberapa bangun saja yang termasuk segitiga. Rata-rata hasil tes awal dari 18 siswa adalah 55.9 dengan prosentase siswa mencapai KKM 11\%. Berdasarkan analisis tes awal, dapat disimpulkan bahwa masih terapat miskonsepsi pada materi bangun datar.

Standar nasional pendidikan menyatakan bahwa materi bangun datar sederhana termasuk dalam ruang lingkup pembelajaran geometri. Pembelajaran geometri dilandasi teori van hiele. Teori van hiele mengkaji tentang tahap berpikir siswa dalam pembelajaran geometri, dimana siswa tidak dapat naik ke tingkat pembelajaran yang lebih tinggi tanpa melewati tingkatan yang lebih rendah. Oleh sebab itu, guru hendaknya menggunakan teori van hiele sebagai pedoman pelaksanaan pembelajaran geometri agar tidak menimbulkan miskonsepsi dalam pembelajaran geometri khususnya pada materi bangun datar.

Dahar (2011) menyatakan upaya memperbaiki kesalahan konsep pada siswa melibatkan dua komponen, yaitu kondisi yang harus dipenuhi agar terjadi perubahan konseptual dan ekologi konseptual yang menyediakan konteks untuk berlangsungnya perubahan konseptual. Kedua komponen tersebut dapat diwujudkan melalui pendekatan konstrukivisme. Implikasi prespektif konstruktivisme menekankan bahwa siswa tidak dipandang sebagai penerima pasif, melainkan bersifatb purposive dan bertanggung jawab atas belajarnya sendiri. Siswa secara aktif membangun pengetahuannya untuk mencapai kebermaknaan. Mengajar bukan sebagai pemindahan pengetahuan, melainkan negosiasi kebermaknaan suatu konsep (Driver, 1988). Oleh karena itu, pendekatan konstruktivisme tepat digunakan untuk memperbaiki kesalahan konsep siswa. Dahar (2011) siswa yang tidak puas dengan konsepsi lama dan dengan konsepsi baru dapat menjelaskan peristiwa-peristiwa lain, terlihatlah segi kegunaan konsepsi baru, dengan demikian proses perubahan konseptual berlangsung dalam diri siswa.

Berdasarkan hasil diskusi dengan tim kolaborasi guru kelas III SDN Pekunden yang didasarkan pada kajian beberapa teori, untuk memecahkan masalah miskonsepsi diperlukan perbaikan pemahaman konsep siswa. Alternatif pemecahan masalah yang dianggap tepat digunakan adalah pembelajaran menggunakan pendekatan konstruktivisme berbasis teori van hiele.

\section{B. METODE PENELITIAN}

Metode yang digunakan dalam penelitian ini adalah penelitian tindakan kelas. Penelitian tindakan kelas 
menekankan keterampilan dan teknik yang dimiliki oleh guru dalam menggali informasi dari sswa untuk memperbaiki masalah pembelajaran. Penelitian ini dilaksanakan pada SDN Pekunden Kabupaten Banyumas dengan subjek penelitian adalah guru dan siswa kelas III yang terdiri daril1 siswa laki-laki dan 7 siswa perempuan.

Data yang dikumpulkan adalah data tentang pelaksanaan proses pembelajaran dengan mengimplementasikan pendekatan konstruktivisme berbasis teori van hiele untuk meningkatkan pemahaman konsep siswa pada pembelajaran matematika materi bangun datar. Data kuantitatif berupa hasil belajar yang diperoleh melalui tes pemahaman konsep siswa. Data kualitatif diperoleh dari lembar pengamatan pada aktivitas siswa, keterampilan guru, wawancara an catatan lapangan yang dilakukan dengan menerapkan pendekatan konstruktivisme berbasis teori van hiele pada siswa kelas III SDN Pekunden. Teknik pengumpulan data yang digunakan dakan penelitian ini berupa observasi, tes, dokumentasi dan catatan lapangan.

\section{HASIL DAN PEMBAHASAN}

Penelitian ini dilaksanakan dalam dua siklus, dimana setiap siklus terdiri dari dua pertemuan. Setiap siklus meliputi kegiatan perencanaan (plan), pelaksanaan (act), pengamatan (observe) dan refleksi (reflect). Kegiatan pembelajaran pada siklus 1 memusatkan pada kondisi pembelajaran untuk mempelajari konsep kongkret. Pada siklus 1, siswa sudah dapat membedakan contoh suatu konsep dan non contoh suatu konsep. Upaya memperbaiki kesalahan konsep dilakukan dengan cara : 1) membandingkan persamaan unsur yang dimiliki kelompok bangun segitiga dan segi empat. Hingga siswa memahami konsep yang benar bahwa kelompok bangun segi tiga memiliki tiga ruas garis (sisi) dan kelompok bangun segi empat memiliki empat ruas garis (sisi); 2) Menanamkan konsep segi empat melalui bangun segi empat sembarang; 3) guru tidak lagi menampilkan bangun datar pada satu sudut pandang saja. Berdasarkan hasil observasi pada perbaikan proses pembelajaran pada siklus 1 terhadap kemampuan pemahaman siswa maka diperoleh data pada Tabel 1 .

Tabel 1. Data Hasil Kemampuan Pemahaman Konsep Siswa Siklus I

\begin{tabular}{llll}
\hline No & $\begin{array}{l}\text { Kemampuan Pemahaman } \\
\text { Konsep Siswa }\end{array}$ & Frek & $\%$ \\
\hline 1 & $\begin{array}{l}\text { Mengelompokkan } \\
\text { bangun yang termasuk } \\
\text { segitiga }\end{array}$ & 18 & 100 \\
\hline 2 & $\begin{array}{l}\text { Mengelompokkan } \\
\text { bangun yang termasuk } \\
\text { segempat }\end{array}$ & 18 & 100 \\
\hline 3 & $\begin{array}{l}\text { memahami nama bangun } \\
\text { layang-layang walaupun } \\
\text { di tampilkan dalam } \\
\text { berbagai representasi }\end{array}$ & 15 & 83 \\
\hline 4 & $\begin{array}{l}\text { memahami nama bangun } \\
\text { trapesium walaupun di } \\
\text { tampilkan dalam } \\
\text { berbagai representasi. }\end{array}$ & 18 & \\
\hline 5 & $\begin{array}{l}\text { memahami nama bangun } \\
\text { jajar genjang walaupun } \\
\text { di tampilkan dalam } \\
\text { berbagai representasi. }\end{array}$ & 7 & \\
\hline 6 & $\begin{array}{l}\text { memahami nama bangun } \\
\text { belah ketupat walaupun } \\
\text { di tampilkan dalam } \\
\text { berbagai representasi }\end{array}$ & & \\
\hline 7 & $\begin{array}{l}\text { memahami nama bangun } \\
\text { persegi walaupun di } \\
\text { tampilkan dalam } \\
\text { berbagai representasi. }\end{array}$ & 90 \\
\hline 8 & $\begin{array}{l}\text { memahami nama bangun } \\
\text { persegi panjang } \\
\text { walaupun di tampilkan } \\
\text { dalam berbagai } \\
\text { representasi }\end{array}$ & 8 \\
\hline & & \\
\hline Rata-rata dalam \% & \\
\hline & & \\
\hline
\end{tabular}

Berdasarkan data pada siklus I menunjukkan bahwa rata-rata pemahaman konsep bangun datar sudah melebihi indikator keberhasilan $75 \%$ namun belum maksimal. Pada siklus I siswa sudah mencapai tingkatan pembelajaran geometri menurut van hiele pada tingkat visualisasi. Pada tingkatan ini siswa sudah mampu mengenal bentuk bangun datar dalam berbagai bentuk representasi serta memahami bangun datar yang termasuk kelompok bangun segitiga dan segiempat. 
Pencapaian konsep menurut klausmeier (1977) terdiri dari empat tingkatan yaitu 1) tingkat kongkret; 2) tingkat identitas; 3) tingkat klasifikasi; 4) tingkat formal. Berasarkan temuan siklus I, siswa sudah mencapai tingkat kongkret dan tingkat identitas. Pada tingkatan ini, siswa sudah mengenal berbagai bentuk bangun datar, membuat generalisasi kelompok bangun yang identik dari bangun datar merupakan anggota dari kelompok bangun datar segitiga maupun segiempat.

Peneliti ingin meningkatkan kemampuan siswa pada tahapan berikutnya. Oleh karena itu, penelitian tindakan dilanjutkan pada siklus berikutnya. Upaya memperbaiki kesalahan konsep hubungan antar bangun dilakukan dengan cara membandingkan dua bangun yang memiliki persamaan sifat berdasarkan teori van hiele. Berdasarkan hasil observasi perbaikan proses pembelajaran pada siklus II terhadap kemampuan pemahaman siswa maka diperoleh data pada Tabel 2.

Tabel 2. Data Hasil Kemampuan Pemahaman Konsep Siswa Siklus II

\begin{tabular}{|c|c|c|c|}
\hline No & $\begin{array}{l}\text { Kemampuan Pemahaman } \\
\text { Konsep Siswa }\end{array}$ & Frek & $\%$ \\
\hline 1 & $\begin{array}{l}\text { menyatakan persamaan } \\
\text { bangun jajar genjang dan } \\
\text { belah ketupat }\end{array}$ & 17 & 94,4 \\
\hline 2 & $\begin{array}{l}\text { menyatakan persamaan } \\
\text { bangun jajar genjang dan } \\
\text { persegi panjang }\end{array}$ & 14 & 77,8 \\
\hline 3 & $\begin{array}{l}\text { menyatakan persamaan } \\
\text { bangun layang-layang dan } \\
\text { belah ketupat }\end{array}$ & 12 & 66,7 \\
\hline 4 & $\begin{array}{l}\text { menyatakan persamaan } \\
\text { bangun persegi panjang } \\
\text { dan persegi }\end{array}$ & 14 & 77,8 \\
\hline 5 & $\begin{array}{l}\text { menyatakan persamaan } \\
\text { bangun persegi dan belah } \\
\text { ketupat }\end{array}$ & 18 & 100 \\
\hline & Rata-rata dalam $\%$ & & 84,34 \\
\hline
\end{tabular}

Berdasarkan data pada siklus II rata-rata pemahaman konsep telah meningkat menjadi $84,34 \%$. Pada siklus II siswa telah mencapai tingkatan pembelajaran geometri menurut van hiele pada tingkat visualisasi, dan analisis. Pada tingkatan ini siswa sudah mampu memahami kesamaan antar dua bangun pada kelompok bangun segiempat. Pada tahap ini siswa sudah mengetahui dan mengenal sisi-sisi berhadapan pada sebuah persegu panjang adalah sma panjang, panjang kedua diagonalnya sama panjang dan memotong satu sama lain sama panjang. Tetapi, siswa belum mampu memahami hubunga nantara bangunbangun geometri. Hal ini sesuai dengan pendapat Clements dan Battista (1992). Kelanjutan tingkat visualisasi dan analisis adalah tingkat abstraksi.

Pencapaian konsep menurut klausmeier sudah mencapai tiga tingkatan yaitu, tingkat kongkret, identitas dan klasifikasi. Pada tingkat klasifikasi, siswa telah mengenal persamaan dari dua contoh bangun datar segiempat yang berbeda dari kelompok bangun datar segiempat. Walaupun siswa belum mampu mengklasifikasikan bahwa setiap bangun segiempat berhubungan, namun siswa dapat mengklasifikasikan contoh dan non contoh yang memiliki kesamaan konsep. Berdasarkan data hasil penelitian menunjukkan bahwa nilai rata-rata tes pemahaman konsep siswa kelas III SDN Pekunden pada materi bangun datar disajikan melalui dalam Gambar 2 berikut.

Tabel 3. Perbandingan Hasil Belajar

\begin{tabular}{llccc}
\hline No & Pencapaian & $\begin{array}{c}\text { Pra } \\
\text { Siklus }\end{array}$ & $\begin{array}{c}\text { Siklus } \\
\text { I }\end{array}$ & $\begin{array}{c}\text { Siklus } \\
\text { II }\end{array}$ \\
\hline 1 & Nilai Tertinggi & 93,75 & 96,43 & 100 \\
\hline 2 & Nilai Terendah & 43,75 & 82,14 & 71 \\
\hline 3 & Rata-rata & 55,90 & 88,69 & 86 \\
\hline 4 & Siswa Tuntas & 2 & 18 & 18 \\
\hline 5 & $\begin{array}{l}\text { Siswa Tidak } \\
\text { Tuntas }\end{array}$ & 16 & 0 & 0 \\
\hline 6 & $\begin{array}{l}\text { Ketuntasan } \\
\text { KKM }\end{array}$ & $11 \%$ & $100 \%$ & $100 \%$ \\
\hline
\end{tabular}

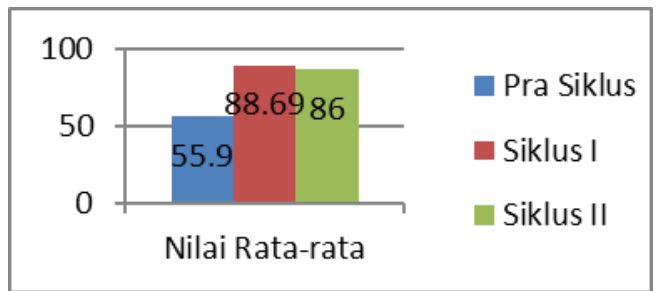


Gambar 2. Rata-rata Nilai Tes

KKM pembelajaran matematika adalah 65. Pada pra siklus terdapat dua siswa yang sudah mencapai KKM, sedangkan pada siklus I dan siklus II prosentase ketuntasan KKM sudah meningkat $100 \%$. Pada siklus I telah nampak terjadi peningkatan. Siklus II dilakukan dengan tujuan meningkatkan tingkat pemahaman konsep siswa pada pembelajaran geometri. Walaupun nilai rata-rata siklus II lebih rendah dari siklus I, namun telah terjadi peningkatan kemampuan pemahaman konsep siswa pada materi bangun datar.

Hasil penelitian Rostika (2012) menunjukkan bahwa minat dan aktifitas belajar siswa meningkat dari kriteria cukup menjadi baik, dan meningkatkan hasil belajar siswa sekolah dasar. Penelitian Rostika didukung oleh hasil penelitian Sukayasa (2015) yang menunjukan bahwa pemahaman siswa SD Karunadipa Palu dapat ditingkatkan dengan menerapkan strategi pembelajaran yang dirancang berdasarkan pendekatan konstruktivisme. Van hiele merupakan teori yang secara khusus dapat digunakan pada pembelajaran geometri. Hasil penelitian Sasmita, Wirya, dan Margunayasa (2013) bahwa hasil belajar kelompok siswa yang mengikuti pembelajaran geometri dengan teori Van Hiele lebih baik dari pada hasil belajar kelompok siswa yang mengikuti pembelajaran geometri dengan menggunakan pembelajaran konvensional.

Kolaborasi teori van hiele dan pendekatan konstruktivisme dapat menjadi alternative yang tepat dalam meningkatkan pemahaman siswa. Peningkatan pemahaman konsep bangun datar dipengaruhi tentunya oleh beberapa faktor. Pembelajaran konstruktivisme meletakkan siswa sebagai subyek pembelajaran, guru hanya berperan sebagai fasilitator. Siswa secara aktif mengkonstruksi pengetahuannya dalam mengamati, menelusuri, serta menemukan dan membuat generalisasi konsep (Sudjana, 2008).
Sebagai fasilitator, guru membimbing dan mengarahkan siswa dalam membangun konsep melalui media kongkret. Oleh karena itu, proses pembelajaran yang dilakukan dalam penelitian ini menggunakan benda kongkret berupa model bangun datar dan gambar. Hal ini sesuai dengan teori Brunner bahwa siswa akan belajar dengan baik jika melalui 3 tahap, yakni enaktif, ikonik dan simbolik (Hawa, 2007). Pada tahap enaktif, siswa harus menggunakan benda nyata dalam memulai belajar matematika. Benda yang diangap kongkrit atau nyata dalam pembelajaran ini adalah model bangun datar segiempat. Pada tahap ikonik berkaitan dengan gambar, lukisan, foto atau film, sedangkan tahap simbolik merupakan tahap pengalaman abstrak (Khoiri, 2014). Penggunaan alat peraga dapat membantu pembentukan dan pemahaman konsep secara aktif pada siswa. Sudjana (2008) belajar akan bermakna bagi siswa apabila siswa aktif dengan berbagai cara untuk mengkonstruksi atau membangun pengetahuannya. Dengan demikian, suatu rumus, konsep, atau prinsip dalam matematika, seyogyanya ditemukan kembali oleh siswa di bawah bimbingan guru. Selain faktor alat peraga, penggunaan teori van hiele pada pembelajaran geometri juga memicu peningkatan pemahaman konsep siswa.

Yadil (2009: 83) mengemukakan bahwa menurut Van Hiele apabila pembelajaran yang dirancang dengan tepat akan dapat meningkatkan tahap berpikir siswa. Dengan demikian, siswa akan dapat meningkatkan pemahaman siswa terhadap konsep yang akan dipelajarinya. Penelitian Lasmita, Margianti, dan Nurhadi menunjukkan bahwa teori balajr van hiele memberikan pengaruh yang tinggi terhadap hasil belajar peserta didik di sekolah dasar pada pembelajaran matematika.

Oleh karena itu, guru seharusnya menerapkan teori van hiele dalam pembelajaran bangun datar, sehingga guru dapat memperhatikan tahap pemahaman siswa. Menerapkan teori van hiele dapat 
menjadi salah satu tindakan yang tepat untuk mengaarkan materi sidat bangu datar. Hal ini disebabkan, teori belajar van hiele menekankan pada tahap pembelajaran yang disesuaikan dengan tahap berpikir peserta didik, tidak sebaliknya peserta didik yang menyesuaikan diri dengan tahap pemelajaran guru. Sehingga, materi pembelajaran dapat dipahami doleh siswa berdasasarkan urutan tingkat kesukarannya.

Khoiri (2014) National Caucil of Teachers of Mathematics (NCTM) Principles and Standards for Scool Mathematic menyatakan bahwa pemahaman konsep matematika dapat dilihat dari tiga aspek, yaitu siswa dapat (1) mendeskripsikan konsep dengan kata-kata sendiri, (2) mengidentifikasi atau memberikan contoh dan bukan contoh konsep, (3) menggunakan konsep dengan benar dalam berbagai situasi.

Pada penelitian ini siswa sudah mencapai dua aspek yaitu mendeskripsikan konsep dengna kata-kata sendiri, dan mengidentifikasi atau memberikan contoh dan non-contoh.

Van Hiele (Gatot, 2008: 114) dalam belajar geometri perkembangan berfikir siswa terjadi melalui lima level, yaitu, level 0 (visulisasi), level 1 (analisis), level 2 (abstraksi), level 3 (d eduktif) dan level 4 (Rigor). Level-level berfikir van Hiele akan dilalui siswa secara berurutan, dimana siswa harus melewati suatu level dengan matang sebelum menuju level berikutnya dengan lima tahap pembelajaran yaitu, tahap 1 (informasi), tahap 2 (orientasi terarah), tahap 3 (uraian), tahap 4 (orientasi bebas) dan tahap 5 (integrasi).

Hasil analisis menunjukkan bahwa tingkat pemahaman konsep siswa pada pra siklus, belum mencapai visualisai, pada siklus I sudah mencapai level visualisasi dan meningkat pada siklus II pada level visualisasi dan analisis.

\section{SIMPULAN}

Proses pelaksanaan PTK dengan judul peningkatan kemampuan pemahaman konsep bangun datar melalui pendekatan konstruktivisme berbasis teori van hiele untuk mendapatkan gambaran kemampuan siswa pada kelas III SDN Pekunden dilakukan dengan 2 siklus. Berdasarkan data yang diperoleh melalui observasi dan tes pemahaman konsep diperoleh gambaran peningkatan pemahaman siswa terhadap materi bangun datar dimana sudah tidak terapat miskonsepsi kelompok bangun segitiga dan segiempat, siswa sudah mengenal bentuk bangun data dalam berbagai bentuk representasi, serta sudah mampu memahami kesamaan antar dua bangun pada kelompok bangun segiempat. Peningkatan ini dapat dicapai dalam dua siklus. Hasilnya secara kualitatif dapat dikatakan baik.

Hipotesis tindakan dalam penelitian ini adalah "jika guru mampu menstimulus siswa secara aktif dalam membangun konsep bangun datar sesuai dengan teori van hiele, maka kegiatan pembelajaran menjadi efektif, yang ditandai dengan tidak terdapat kesalahan konsep pada siswa dan tewujudnya kemampuan pemahaman konsep siswa. Hipotesis ini dapat terbukti berdasarkan proses dan hasil pengumpulan data, analisis data, dan pembahasan.

\section{DAFTAR RUJUKAN}

Ausubel. (1968). Educational Psycology: A Cognitive View. New York: Holt, Rinehart, and Winston

Clements, D. H., \& Battista, M. T. (1992). Geometry and Spatial, New York : Macmillan Publishing

Dahar. R.W. (2011). Teori-teori Belajar dan Pembelajaran. Jakarta : Erlangga

Driver, R. (1988). Changing Conceptions. Tidjschrift voor didaktiek derwetenschappenoe, jaargang, 6(3), 161-198.

Muhsetyo, G., Krisnadi, E., Karso, K., Wahyuningrum, E., Tarhadi, T., \& Djamus, D. (2008). Materi Pokok Pembelajaran Matematika SD. Jakarta: Universitas Terbuka. 
NCTM. (2000). Mathematics Assessment: a Practical Handbook for grade 6-8. Reston : Virginia.

Hawa, S. (2007). Teori Belajar Bruner Pembelajaran Matematika Sekolah Dasar. Universitas Terbuka

Khoiri, M. (2014). Pemahaman Siswa Pada Konsep Segiempat Berdasarkan Teori Van Hiele. Prosiding Seminar Nasional Matematika, Universitas Jember, 19 Nov 2014.

Klausmeier, H.J. (1977). Educational Experience and Cognitive Development. Educational Psychologist, 12(2), 179-195

Lisa Rostika, D. (2008). Pembelajaran Volume Bangun Ruang Melalui Pendekatan Konstruktivisme untuk Siswa Sekolah Dasar. Jurnal Pendidikan Dasar, 9(1).

Sasmita, I. G. A. L., Wirya, I. N., \& Margunayasa, I. G. (2013). Pengaruh Teori Van Hiele Dalam
Pembelajaran Geometri Terhadap Hasil Belajar Siswa Kelas V SD di Desa Sinabun. Jurnal Mimbar $P G S D, 1$.

Sudjana, A. (2008). Pengenalan Bangun Datar dan Sifat-sifatnya di SD. Yogyakarta : PPPPTK

Sukayasa. (2015). Penerapan Pendekatan Konstruktivis Untuk Meningkatkan Pemahaman Siswa SD Karunadipa Palu Terhadap Konsep Volume Bangun Ruang. Jurnal Kreatif. 18(1)

Yadil. 2009. Penerapan Model Pembelajaran Van Hiele Untuk Meningkatkan Pemahaman Siswa SMP Karunadipa Palu Terhadap Konsep Bangun-bangun Segiempat. Prosiding Seminar Nasinal Matematika dan Pendidikan Matematika Jurusan Pendidikan Matematika Universitas Negeri Yogyakarta 5 Des 2009. 